\title{
sobre: Interpelaciones. Indicios y fracturas en textos latinoamericanos, de Luz Rodríguez Carranza. villa Maria:
}

\author{
EDUVIM, 2019
}

LUCIANA IRENE SASTRE Universidad Nacional de Córdoba, Argentina / luchisastre@hotmail.com

Podríamos hablar de una poética en la escritura crítica cuyas pistas están en una exhibición temporal que juega con nuestro deseo y nos pide cosas imposibles: ir a contramano, leer a contrapelo, dos figuras que nos dan la pauta de un absurdo realizado cuando termina el libro y es que comprendemos hacia atrás porque todo estaba dicho hacia adelante. Actuamos, entonces, como espías tardíos de un texto magistral, que nos ha conducido por una topología que revela la ilusión de las fracturas mediante un trabajo isométrico de exhibición de las continuidades hasta que ese estiramiento gomoso de la realidad no soporta y el hilo se corta por lo más delgado o, al revés, hasta que allí donde se decía desaparición, tenemos las sobrevivencias. Esto es posible o I did it, ley de archivo de esta selección. Propongo que esto es un desatino, y he hallado datos acerca de la familiaridad etimológica, la tiene para nosotros el juego sonoro en la medida que en repetidas ocasiones se acercan en el libro de Rodríguez Carranza la idea de destino y la de su rechazo.

El libro comienza con algo que va más allá del prólogo. Se trata de una apertura perfomativa, me atrevo incluso a decir que se trata de una instrucción performática, pues el trabajo que sigue para la lectura será, en muchos casos y por distintos motivos, una labor sin mapa ni compás sobre el comportamiento humano, como dice un verso de Björk. Aquí se nos presentan los desviados o, mejor dicho, los desviantes «malos sujetos», que serán los que señalen que el rey va desnudo mientras la comitiva siga acomodando la inexistente cola del fastuoso atuendo. Según el cuento de Andersen, es un niño el que grita la verdad, los adultos le señalan su inocencia, el rey decide seguir hasta el final. Ese niño, nos interesa.

Interpelaciones. Indicios y fracturas en textos latinoamericanos consta de 5 capítulos, que el prólogo anuncia cronológicos, y eso es una intriga bien sembrada, porque la potencia combinatoria de una bibliografía sumamente ecléctica, abundante e irreverente, nos distrae del tiempo, aunque no se trate en este caso de un señuelo sino una declaración honesta. Del mismo modo, se entrama en cada categoría una poética del tiempo entretejida con una teoría de la imagen y una teoría del sujeto. Simultáneamente, tenemos un ejercicio de archivo a primera vista, pero la construcción

Para citar este artículo: Sastre, L.I. (2020). Sobre: Interpelaciones. Indicios y fracturas en textos latinoamericanos, de Luz Rodríguez Carranza. El taco en la brea, 11 (diciembre-mayo), 188-191. Santa Fe, Argentina: UNL. DOI: 10.14409/tb.v1i11.9167 
del archivo de la literatura latinoamericana es la consignación caótica por definición, luego, lo que exhibe el trabajo profundiza aún más en las fiebres arcónticas. Es el llamado de la crítica, que se dirime a sí misma en la carrera literaria y que las revistas domicilian, cuyo objeto de deseo son los años 60 y la voz continental. Hay un cambio de paradigma que se denota en el paso de la labor crítica a la investigación. En esta última son el desarchivo, el contra-archivo y el anarchivismo las maquetas de los mecanismos de resguardo de nuestra historia, porque basta un comentario cruzado para que 20 años después, esa mención sea las tres líneas de vida, o el sistema omniexplicativo sea la maquinaria de muerte de un objeto literario cuyo espectro habla vinculado a una iniciativa individual en el marco de la memoria cultural.

El mecanismo, dicho brevemente, moviliza la consecución de los textos, comenzando por la construcción de la juventud como agente de deseo estereotipadamente extirpado de la teleología histórica a fuerza de ser dichos por otros, ya no jóvenes o al menos no parte de ese otro juvenil en cuestión. Pero precisamente, es el estiramiento conceptual de la juventud el que nos lleva a detectar la potencia performativa de su forma asamblearia que es llama en las calles cordobesas en 1969, y es heredera de las «superficies de placer», que cantaba Federico Moura, a fines de los ochenta. Estas últimas en la revista Babel traen al texto a un Sade que empieza por emancipar las imágenes que se saborean durante la lectura cuyas escenas nos hacen experimentar que, cerrando los ojos, estamos desencadenados. Y esto no es sumergirnos en la privatización del deseo sino recordarnos el desencuentro con las estructuras simbólicas, con nuestras reservas imaginarias y con nuestros aparatos de gobierno. Luego, lo que nos interpela, es la sobrevivencia de una pregunta que nos expone al desencadenamiento social después de que Sade ha dejado de ser subversivo o ha perdido la voz, porque todos cerramos los ojos, en una década enmudecida, supuestamente.

La apertura del archivo nos conduce al borde, a la anticipación de que lo que se abisma es la comprensión, el percepto, el concepto, la consigna y el afecto. Sin embargo, allí mismo, el desvío es inestético, es la suspensión para pasar al arte como laboratorio alquímico de destrucción del logos. Luz nos salva con otro estereotipo: Tanguito, según la película Tango feroz, dirigida por Marcelo Piñeyro. La mala película, los malos sujetos, la mala literatura podríamos decir para renombrar «la palabra bruta» (105) de Blanchot o la «archi-escritura» (107) de Oscar del Barco, donde «reina la metamorfosis, donde todo es posible», ante los ojos del lector agrego yo.

Ahora bien, las actas del archivo abierto entre la juventud y Sade, comportan esa exhumación que no repara, que no sutura, que no acomoda, sino que mantiene el nerviosismo de nuestra estereotipación imagética. Porque como cuando a Benjamin le piden que escriba sobre el presente, y él decide cronicar su infancia para documentar lo que está en peligro de desaparición, lo que ya ha desaparecido para él — por eso lo narra en ocasión de otra cosa—, nos interpela aquí qué sucederá cuando seamos leídos con la lente del «objeto Sade» y se nos exhiba en una escritura insoportable, con la "potencia combinatoria» (118) que, en la fórmula de Germán Leopoldo García, asegura que alguien en el futuro detecte el rastro de nuestro pasaje.

Todo el tratamiento de la juventud provoca un afecto de ansiedad que podría traducirse como algo que profanar o, mejor dicho, algo que sobrevive profano, pues se coloca el análisis siempre en el lugar de la válvula de escape que asegura la ineficacia, para decirlo en sus términos, de los malos sujetos. Podríamos tomar como paradigma su análisis de los infames de Borges que es también el de un Borges infamado, elaborado con el dispositivo del héroe para visibilizar los movimientos narrativos que administran la creencia desde el mismo lugar que la sostiene. Esto es una pipa, 
sería su ironía, y la operación de escritura performática mayor, no solo en lo que respecta a la tarea de construcción de un público lector antifascista en los años 30, sino del archivo crítico de las imágenes borgeanas.

Es claro que, junto con la precisión teórica y la comunicabilidad que articula a Aristóteles y a Batman, este libro encarna en nuestra propia mirada de sí. Nos ponemos nosotros mismos bajo la lente sadiana y tenemos una anécdota, hasta un chisme, que devolverle a este texto interpelante. En este punto, el trabajo acerca del ready-made es uno de los lances inesperados. Llegamos a Duchamp para cuestionar la experiencia con otros malos sujetos — Lispector, Lamborghini, Oiticica, y algunos malos sujetos colectivos como La onda o El Crack en México- para volver a un punto crucial: la identificación y el realismo. Casi como si este fuera la manifestación literaria documental de la exigencia de confesarse, de identificarse; no solo se niegan, sino que exhiben la intemperie referencial. Es decir, vuelven a ese lazo de la novela con su afuera pero de lograr el contacto, lo que se suspende es el afecto, el éxito, en consecuencia, la inutilizan como género, la muestran en su impotencia. Esto, para el debate crítico, pero en cuanto al debate estético, son formadores de público como Borges en la época del folletín o, haciendo un esfuerzo poético, podríamos decir que forman lo público según la eficacia estética: ese impasse, ese quiasmo fundamenta, paradójicamente la u-topía consecuente a la desesperada búsqueda del realismo, y de la historia:

El proceso parece irreversible: el lenguaje, una vez adquirido, deja fuera la experiencia muda, la reemplaza marcando su límite y su desaparición. Es lo único que tenemos, sin embargo, el lugar en el que vivimos después de la caída, y es, también, el instrumento de nuestra ceguera por excelencia. Si, como advierte Ludmer, el problema «es leer el hecho crucial de que "lo anterior" está presente en el presente», eso implica también (...) que aquello que parece más comprendido y distante, vale decir la historia, también puede tocarnos de cerca y ser tan extraño, incomprensible y maravilloso como los acontecimientos más inmediatos: puede constituir una experiencia. La historia vive cuando se la asume como narración presente en los verbos, y en los deícticos que, como lo señala también Agamben, se apropian de la lengua en primera persona. La experiencia vive en las palabras-indicios, en los nombres que son su huella, su nostalgia y su potencialidad. (247)

Lo cierto es que, ya hacia el final del libro se abre esta inmensidad de la palabra que es el revés de la rebeldía identificatoria: el nombrar. Es como un desplante, un acto ridículo que puede desembocar en un tremendo melodrama, en una caricatura, en la desavenencia del bios. Pero la advertencia es que todo puede salir bien como señala el análisis de La fuente de César Aira. La novela se termina como diezmada por la tensión entre la caricatura del narrador realista y la emancipación de la irracionalidad. Toda una parodia de la autonomía del texto, todo un chiste sobre el fracaso de la novela, toda una artimaña de la bobería peligrosa de los nacionalismos, toda una conquista irreverente, sádica, otra vez, de la posibilidad de nombrar en la u-topía literaria. La experiencia escrituraria pone en primer plano el andamio inútil de la causalidad y la evolución.

Donde Aira termina su teoría de la novela, cuando ya no puede seguir contando, entran en escena el cine y el teatro, Iñárritu y Spregelburd, en el capítulo titulado «I did». La teoría de la imagen y la teoría del sujeto se anudan en una teoría de los actos puros entendidos como aquellos que están más allá de toda equivalencia y de todos los criterios de eficacia, que encierran en sí mismos su propio propósito (333). Rodríguez Carranza cita a Alenka Zupančič, quien los resuelve en forma de 
refrán, que es deseo eterno: los actos puros son como volver a nacer. Todo el trabajo nos ha llevado a ese permiso final, a ese desencuentro acontecimental con la ajenidad para enfrentarnos con el deseo indómito de que todo puede ser diferente, pero depende de nosotros la posibilidad misma, no los resultados. 